\title{
Estimation of permafrost thawing rates in a sub-arctic catchment using recession flow analysis
}

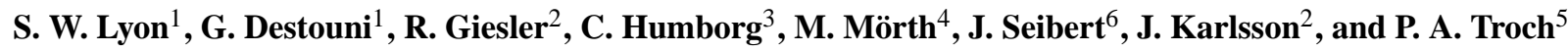 \\ ${ }^{1}$ Physical Geography and Quaternary Geology, Stockholm University, Sweden \\ ${ }^{2}$ Climate Impacts Research Centre, Department of Ecology and Environmental Science, Umeå University, Sweden \\ ${ }^{3}$ Applied Environmental Science, Stockholm University, Sweden \\ ${ }^{4}$ Geology and Geochemistry, Stockholm University, Sweden \\ ${ }^{5}$ Hydrology and Water Resources, University of Arizona, USA \\ ${ }^{6}$ Department of Geography, University of Zurich, Switzerland
}

Received: 21 October 2008 - Published in Hydrol. Earth Syst. Sci. Discuss.: 6 January 2009

Revised: 5 May 2009 - Accepted: 5 May 2009 - Published: 12 May 2009

\begin{abstract}
Permafrost thawing is likely to change the flow pathways taken by water as it moves through arctic and subarctic landscapes. The location and distribution of these pathways directly influence the carbon and other biogeochemical cycling in northern latitude catchments. While permafrost thawing due to climate change has been observed in the arctic and sub-arctic, direct observations of permafrost depth are difficult to perform at scales larger than a local scale. Using recession flow analysis, it may be possible to detect and estimate the rate of permafrost thawing based on a long-term streamflow record. We demonstrate the application of this approach to the sub-arctic Abiskojokken catchment in northern Sweden. Based on recession flow analysis, we estimate that permafrost in this catchment may be thawing at an average rate of about $0.9 \mathrm{~cm} / \mathrm{yr}$ during the past 90 years. This estimated thawing rate is consistent with direct observations of permafrost thawing rates, ranging from 0.7 to $1.3 \mathrm{~cm} / \mathrm{yr}$ over the past 30 years in the region.
\end{abstract}

\section{Introduction}

Detectable climate change is occurring in the arctic and subarctic (Serreze et al., 2000). Numerous studies have reported on the hydrological manifestations of such change: decreasing depth and duration of snowcover (Brown and Braaten, 1998; Curtis et al., 1998), warming and thawing of the permafrost (Stieglitz et al., 2003; Walvoord and Striegl, 2007; Osterkamp, 2007), and increasing precipitation frequency

Correspondence to: S. W. Lyon

(steve.lyon@natgeo.su.se) and amount (McCabe et al., 2001; Walsh, 2000). Climate change is believed to cause an acceleration of the hydrologic cycle in many northern regions seen in increasing freshwater discharge (Peterson et al., 2002) and earlier spring flood peak discharges (Déry et al., 2005). Little is known about how climate change will affect the pathways that water takes as it moves through the landscape to the stream.

Hydrological pathways of water are important in these northern systems. For example, their location and distribution directly influence the biogeochemistry of terrestrial water. There are, for instance, two possible main effects on the carbon cycling at northern latitudes under the influence of climate change and resulting changes in terrestrial hydrology. Increasing precipitation and surface temperature may lead to increasing runoff and snowmelt from the landscape and increasing freshwater flow in streams (Déry and Wood, 2004). This means that more water may be flowing through the highly organic superficial soils of arctic and sub-arctic systems promoting the transport of dissolved organic carbon (DOC) from the landscape (Dutta et al., 2006). This hypothesis implies a positive feedback on atmospheric $\mathrm{CO}_{2}$ via climate change in northern latitudes because increased DOC levels in streamflow would increase respiration and carbon utilization in surface freshwater systems leading to increases in atmospheric $\mathrm{CO}_{2}$ levels (Jansson et al., 2008). Increasing temperatures may also lead to thawing permafrost that increases groundwater flow through mineral soils that in turn increases weathering. Depending on the magnitude of $\mathrm{CO}_{2}$ consumption during weathering, this scenario could constitute a negative feedback of climate change on atmospheric $\mathrm{CO}_{2}$ (Smedberg et al., 2006).

Published by Copernicus Publications on behalf of the European Geosciences Union. 
A key determinant of the relative magnitude of these two climate feedback possibilities is the re-distribution of the flow pathways of water through the landscape. In many arctic and sub-arctic regions these pathways are largely determined by the depth to the permafrost. Direct observations of depth to permafrost are difficult to perform at scales larger than the local scale. This difficulty leads to a lack of longterm observation records of depth to permafrost. However, it may be possible to infer changes in the effective depth to permafrost (thawing rate) from the hydrologic signature imparted on long-term flow records by the landscape. Recession analysis is a hydrological technique that has been used in many studies to estimate effective, catchment-scale hydrologic parameters (e.g., Brutsaert and Nieber, 1977; Troch et al., 1993; Parlange et al., 2001; Rupp and Selker, 2006a). In a recent study, Brutsaert (2008) applied recession analysis to demonstrate long-term changes in groundwater storage.

Previous process-based studies have used flow and recession characteristics to help quantify the response of and characterize the hydrologic processes of arctic and sub-arctic hydrologic systems. Dingman $(1966,1973)$ used hydrograph characteristics to describe the influence of permafrost position on formation of high water tables leading to surface runoff. Ice layers at the interface of the organic and mineral soils have often been cited as the main cause of lateral runoff in northern systems (Kane et al., 1981; Roulet and Woo, 1988; McNamara et al., 1997), with much research emphasizing their role in water storage and restriction of transmittance properties (Santeford, 1979; Slaughter and Kane, 1979; Hinzman et al., 1993; McNamara et al., 1998). Subsurface flow can, thus, become a main mechanism for the rainfall-runoff generation on mountainous slopes (Kuchment et al., 2000). Carey and Woo (2001) used recession analysis to identify contributing areas to runoff production, which varied greatly between events. Yamazaki et al. (2006) looked at recession gradients and attributed monthly variations to seasonal changes in active layer thickness. While such studies have advanced our understanding of the hydrologic processes that occur in arctic and sub-arctic regions, they have often been limited to relatively short (typically $<10$ years) of observations and, thus, unable to investigate the long-term responses of arctic and sub-arctic systems to changes in climate (Woo et al., 2008).

In this study, we use recession flow analysis as outlined by Brutsaert and Nieber (1977) to investigate the possible permafrost thawing rate in response to climate change in a sub-arctic catchment using a long record of observed streamflow. Our main hypothesis is that thawing of permafrost extends the depth of the active groundwater system layers in which groundwater flow can occur during the summer season. Using recession flow analysis we can then estimate the extending aquifer thickness, as explained below.

\section{Recession flow analysis and theory}

Here only a short description of recession flow analysis is given. A thorough and complete discussion of this technique (including discussion of the strengths and weaknesses) is given by Brutsaert $(2005,2008)$.

Physical considerations based on hydraulic groundwater theory suggest that in many situations of interest the total groundwater storage in a catchment can be approximated as a power function of baseflow rate at the catchment outlet (Brutsaert, 2008):

$d Q / d t=-a Q^{b}$

where $d Q / d t$ is the temporal change of the flow rate at the outlet during flow recession and the constants $a$ and $b$ give the intercept and slope of a plot of $d Q / d t$ versus flow $Q$ in log$\log$ space, respectively. For several well-known solutions of the Boussinesq equation $a$ can be related to aquifer properties and $b$ may assume a certain constant values depending on time since the onset of drainage, bedrock slope and reservoir properties (Brutsaert, 2005). In practice, this recession analysis consists of relating the rate of decline of the hydrograph, which is assumed to result solely from groundwater storage (i.e., periods of record when there is no forcing due to rainfall or snowmelt), to observed hydrograph outflow (Fig. 1a).

It is not easy to determine the value of the constant $b$ in an objective way due to invariably noisy streamflow observations (Brutsaert, 2008), although conceptually appealing arguments can be made for some of the theoretical formulations. This being said, accepting a value of $b=1$ implies an exponential decay function for the flow rate (essentially the aquifer responds as a linear reservoir). Analysis of much field data (including those used in this study, see Fig. 2) indicates that in the range of the lowest flows, the flow recession can usually be fitted by an exponential decay function making it the most commonly used function today (Brutsaert, 2008). For the long-time solution of the fundamental harmonic linearized solution to the Bousinessq equation (Brutsaert, 2005), these constants (specifically the intercept) can be related to aquifer properties such that:

$b=1$

$a=\pi^{2} k p D L^{2}\left(n_{e} A^{2}\right)^{-1}$

where $k$ is the hydraulic conductivity, $p$ is an empirical weighting constant ranging roughly between 0.3 and 0.1 or perhaps even smaller as the water table further declines in the range of lowest flows (Brutsaert, 2008), $D$ is the depth of the aquifer, $L$ is the total length of the channel network, $n_{e}$ is the drainable porosity, and $A$ is the catchment area. This solution assumes that the change in saturated thickness over the course of a recession event is small relative to the total saturated thickness. 
(a)
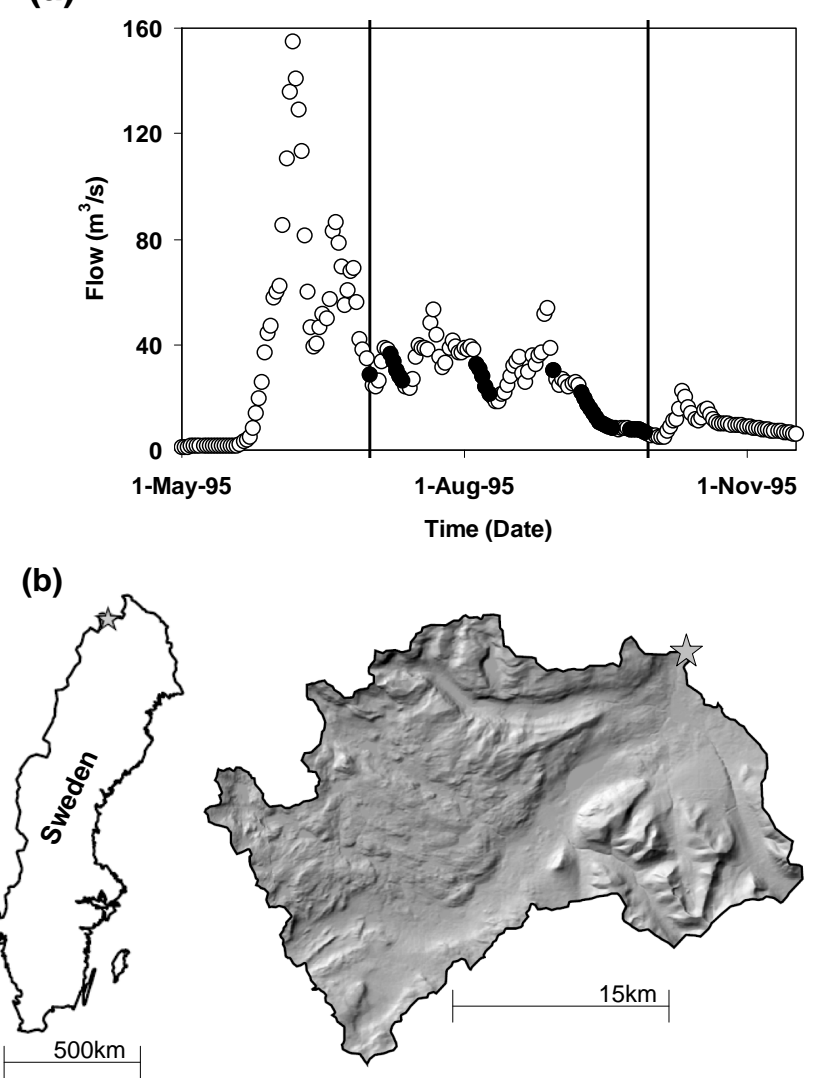

Fig. 1. (a) Example daily outflow hydrograph showing period of record (July-September marked with vertical lines) used in recession flow analysis and days of recession highlighted (filled black circles). This hydrograph is for the (b) the Abiskojokken catchment in northern Sweden with the outlet (indicated by a star) at $68^{\circ} 21^{\prime} 36^{\prime \prime} \mathrm{N}, 18^{\circ} 46^{\prime} 48^{\prime \prime} \mathrm{E}$.

Typically, $a$ and $b$ in Eqs. (2) and (3), respectively, are assumed to be constant in time as they are dependent on the physical (both geomorphologic and hydrologic) characteristics of the catchment in question (Brutsaert, 2008). If we can assume that there are no changes in the fit of an exponential decay function to describe the flow recession for a catchment (i.e., $b=1$ remains constant), it should be possible to observe changes in the physical characteristics of a catchment by observing changes in the intercept $(a)$ of a plot of $d Q / d t$ versus $Q$ over a long period of time.

The question then is what physical characteristics would we expect to change at the timescale of human observation for a given catchment? In arctic and sub-arctic regions containing a permafrost layer, which functions as an impervious layer, the depth of aquifer $(D)$ given in Eq. (3) is closely related to the depth to and extent of permafrost. Permafrost thawing should imply increasing $D$, since groundwater flow and aquifer depth can only be added by the thawing, and there is no physical mechanism involved to decrease the

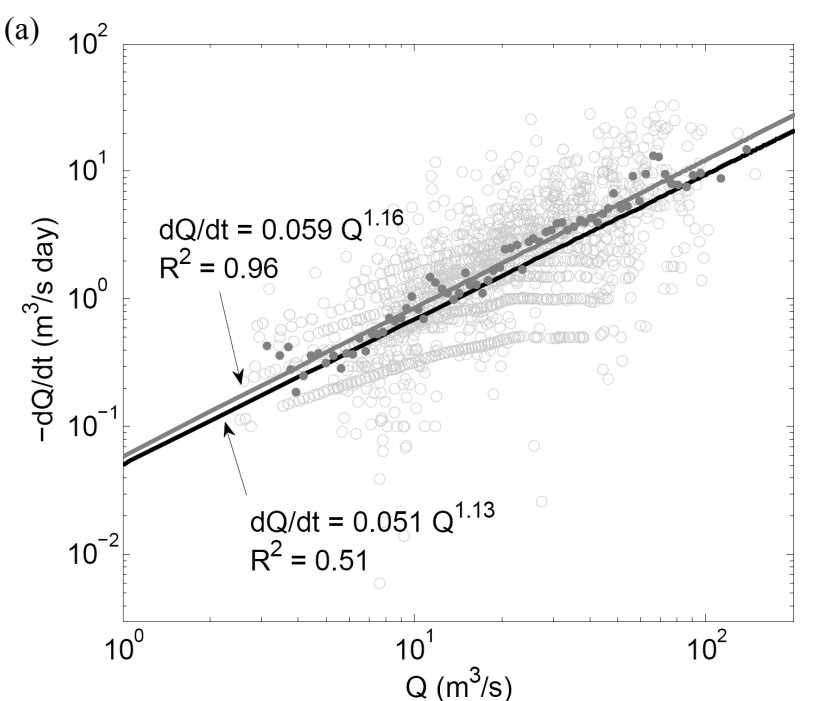

(b)
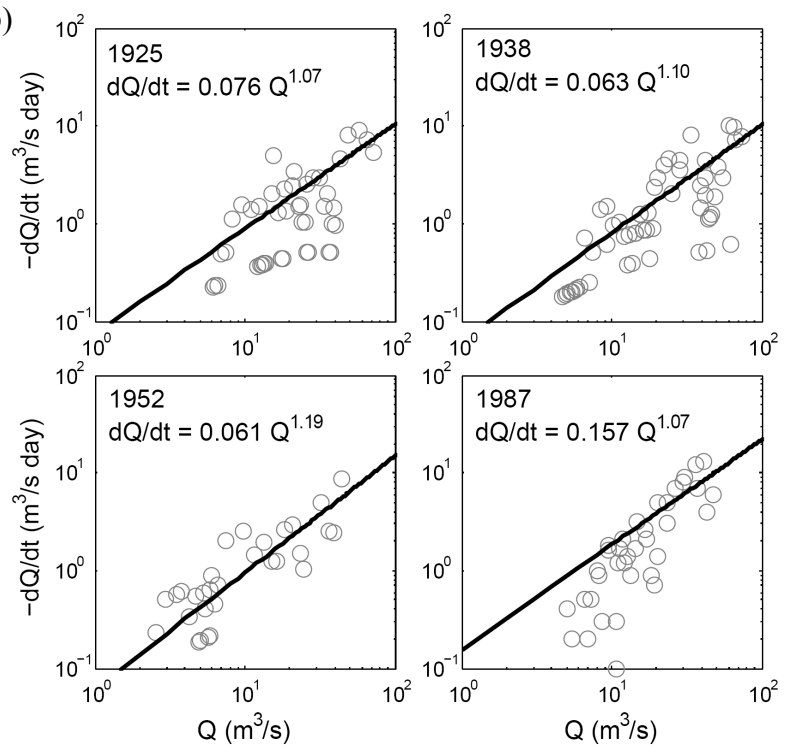

Fig. 2. $Q$ versus $d Q / d t$ in $\log -\log$ space. The black straight line represents Eq. (1) from the recession flow analysis for (a) a nonlinear least squares fitting to all data points (gray circles) for all years (1918-2007) and the darker gray line corresponds to the dark gray points created using the binning method suggested in Kirchner (2009). Adopting the nonlinear least squares approach, we can also fit Eq. (1) to (b) selected years of flow data from Abiskojokken catchment.

original pre-thawing groundwater flow or depth. This is, of course, considering permafrost thawing as a long-term process, in addition to the seasonal fluctuations of the active layer. Therefore, using long-term flow observations, we should be able to infer changes in the effective depth to permafrost at the catchment scale using Eq. (3). Inherent to this hypothesis is the assumption that there is no change in the geomorphic characteristics ( $L$ and $A$ ) and no (or relatively small) change in the hydrologic characteristics $\left(k\right.$ and $\left.n_{e}\right)$ in Eq. (3). 


\section{Site description and data set}

To test the above-described hydrological methodology to detect thawing of permafrost, we apply it to long-term daily streamflow data from the outlet of the sub-arctic Abiskojokken catchment (Fig. 1b) located in northern Sweden $\left(68^{\circ} 21^{\prime} 36^{\prime \prime} \mathrm{N}, 18^{\circ} 46^{\prime} 48^{\prime \prime} \mathrm{E}\right)$ for the period 1918-2007. This streamflow record is available through the Swedish Meteorological and Hydrological Institute (SMHI) (Gage ID 957) and is not continuous throughout the whole period; observation was discontinued at this gage from 1956 through 1986. While observation was discontinued, there were no changes in the sampling location or the stage-discharge relationship between the two time periods (1918-1956 and 1986-2007). We analyze also long-term daily temperature, precipitation and snow cover data for the Abiskojokken catchment, which are available from the Abisko Scientific Research Station (ANS) for the period 1913-2006.

The Abiskojokken catchment has an area of $566 \mathrm{~km}^{2}$ and ranges in elevation from about $350 \mathrm{~m}$ to $1600 \mathrm{~m}$ a.s.l. The catchment contains both alpine and subalpine vegetation zones. The alpine region is dominated by heath vegetation mainly as dwarf shrubs and the subalpine zone by birch forest with patches of dwarf shrubs. Wetlands and marshes can also be found in the subalpine zone and at lower altitudes in the alpine zone. Soils at higher altitudes in the alpine zone are thin with common occurrences of exposed bedrock while soils in the low- and mid-alpine zone are generally thicker. The average soil depth in the adjacent headwaters of the river Kalixälven with a similar elevation range has been estimated to be about 1.7 to $5.3 \mathrm{~m}$ (Smedberg et al., 2006). Regolith depths in the Abiskojokken catchment can be greater than $30 \mathrm{~m}$ (Beylich et al., 2004). The Abiskojokken catchment is in an area of discontinuous permafrost (Johansson et al., 2006) with a patchy distribution generally occurring above $900 \mathrm{~m}$ a.s.l. (Kling, 1996). Permafrost in the area has been documented down to a depth of $80 \mathrm{~m}$ below surface at high altitudes (Kling, 1996) and exists also at lower elevations (Johansson et al., 2006).

\section{Methods}

To investigate how the depth and extent of the permafrost and the related active groundwater layers may have changed over time at the catchment scale, we use a five-year moving window analysis to create multiple subsets of recession flow data from the long-term hydrograph observations. Performing the above outlined recession flow analysis on each individual subset of the flow record, we identify changes in the intercept, $a$, of the $d Q / d t$ versus $Q$ plot, which are in turn related to aquifer depth $D$. Following Brutsaert and Nieber (1977) and Kirchner (2009) the flow recession was defined as the difference in discharge between two successive days, $-d Q / d t=\left(Q_{t-\Delta t}-Q_{t}\right) / \Delta t$, and plotted as a function of the average discharge over the two days, $\left(Q_{t-\Delta t}+Q_{t}\right) / 2$.

To isolate periods of recession flows resulting solely from groundwater storage, we consider only snow free periods of the flow record (July-September) determined from the snow cover observation record (Fig. 1a). It is possible that scattered, relatively small patches of snow cover still exist at higher elevations during early July. However, between sublimation, evaporation of ponded water, and root water uptake the influence of melt water from these patches is assumed to do little to influence recession flow. Also, periods of the streamflow record influenced by rainfall are eliminated from the recession analysis by removing days when the hydrograph is rising (presumably in response to rainfall) and three days following each hydrograph peak. Focusing on the summer period further ensures that perched groundwater system exists above the permafrost that contributes shallow subsurface flow to the channel network. In winter this flow pathway is inactive due to frozen soil conditions (see supplementary material: http://www.hydrol-earth-syst-sci.net/13/595/ 2009/hess-13-595-2009-supplement.pdf).

In addition, to test the assumptions made in adopting Eqs. (2) and (3) for the linearized solution to the Bousinessq equation, we perform a recession flow analysis fitting Eq. (1) in log-log space to a plot of all data for $d Q / d t$ versus $Q$ over the entire period of record. Fitting in this analysis and throughout this study is performed using a nonlinear least squares fitting function from MATLAB r2007b. This method of fitting to all data points avoids issues associated with defining a lower envelope to the cloud data points resulting from a recession flow analysis (although, we do consider this approach as well, see following results section). However, as discussed by Rupp and Selker (2006b), the spread in $d Q / d t$ at any particular value of $Q$ may be due to stochastic variability and measurement noise complicating our ability to fit Eq. (1) to all data points on a $d Q / d t$ and $Q$ plot. Also, discretization may occur by adopting a constant time step to define changes in flow (Rupp and Selker, 2006b). Kirchner (2009) provides a methodology to address this issue of "noise" by binning the $-d Q / d t$ data in increments of $Q$ such that each bin spans at least $1 \%$ of the logarithmic range in $Q$, and that include enough points that the standard error of $-d Q / d t$ within the bin is less than half of its mean (Kirchner, 2009). Then, fitting occurs on the mean for each bin $Q$ and resulting bin of $-d Q / d t$. According to the argument of Kirchner (2009), this approach keeps highly uncertain points from exerting too much influence on the regression and it yields the maximum-likelihood estimator for the best fit curve. This is given the deviations of the mean from the true relationship is approximately normal. We use the methodology of Kirchner (2009) to test and validate the appropriateness of the methodology in this study using the nonlinear least squares method to fit Eq. (1) to all data points in a plot of $d Q / d t$ vs. $Q$. 


\section{Results}

Figure $2 \mathrm{a}$ shows the nonlinear least squares fit of Eq. (1) to the plot of $d Q / d t$ versus $Q$ in $\log$-log space for all recession flow data from the 1918-2007 observation record. The fitted slope of $b=1.13$ supports the use of Eqs. (2) and (3) for relating the physical characteristics of the aquifer and catchment to the observed recession flows (as opposed to other solutions - see Brutsaert, 2005). Using the methodology of Kirchner (2009), we obtain a similar slope $(b=1.16)$ further justifying adopting Eqs. (2) and (3) for this catchment (Fig. 2a). In addition, agreement between the methods of Kirchner (2009) and the nonlinear least squares fitting to all data points, demonstrates that nonlinear least square fitting of Eq. (1) to all data points is appropriate and robust for the level of uncertainty and noise associated with the stream flow observations for the Abiskojokken catchment over the past 90 years when analyzing data from different individual years (Fig. 2b). Thus, it is adopted as an adequate methodology for the remainder of this study.

Using the five-year moving window of recession flow data over the whole streamflow record, we find a significant $(p<0.05)$ positive linear trend in the intercept $a$ for Abiskojokken from 1918 through 2002 (Fig. 3) by nonlinear least squares fitting Eq. (1) to all points (approach supported by Parlange et al., 2001) and holding $b=1$ constant. The significance of this trend holds also if we use a larger, ten-year moving window for defining the subsets of recession flow data from the whole flow record. For comparison, we also find a significant $(p<0.05)$ positive linear trend in the intercept $(a)$ if the power law relation is fitted to a lower envelope of points (approach supported by Brutsaert and Nieber, 1977) (analysis not shown). Owing to the difficulty associated with defining the lower envelope of the cloud of points in a plot of $d Q / d t$ versus $Q$, however, we adopt and consider the results obtained by fitting all points for the remainder of this study. Note that fitting a linear trend over the entire time span of observations (1918-2007) incorporates the period of no observations (1956-1986). Fitting each period of observations separately such that we consider the data from 1918-1956 separate from 1986-2007, the slope of the linear trend for each period (0.0006 and 0.0007 for 1918-1956 and 19862007 , respectively) is similar to that of the slope of the linear trend fit over the entire time span of observations $(0.0006$ for 1918-2007). This signifies that the linear trend over the entire period is not likely to be an artifact of any step-shift change of conditions between the two time periods.

Looking at the climatic data over this period, there is a positive linear trend (not significant) in annual average temperatures (Fig. 4a). There is a significant $(p<0.05)$ positive linear trend in the spring (average from April to June) temperatures (Fig. 4b). Kohler et al. (2006) report an average annual air temperature from 1913 to 2004 of $-0.6^{\circ} \mathrm{C}$ for this location. Based on many investigations in Fennoscandia, King (1986) put the boundary between regions of continuous and discontinuous permafrost at approximately the $-6^{\circ} \mathrm{C}$ isotherm and the limit between discontinuous and sporadic permafrost zones at approximately the $-1.5^{\circ} \mathrm{C}$ isotherm of the mean annual air temperature. Active layer thickness is determined primarily by summer conditions while permafrost temperatures reflect changes in mean annual conditions (Serreze et al., 2000; Johansson et al., 2006). The positive trends in air temperature along with a long-term average annual air temperature above the limit for maintaining a continuous permafrost layer provides the mechanistic explanation for the permafrost thawing that is indicated by the recession analysis.

For the long-term changes in the hydrologic fluxes for the catchment, there are slight positive linear trends (not significant) in both total annual precipitation (Fig. 5a) and summer (July-September) precipitation (Fig. 5b). With regard to streamflow, there is a positive linear trend (not significant) in both the total annual flow (Fig. 5c) and the non-winter (total from April to November) streamflow (Fig. 5d), and a significant $(p<0.05)$ negative linear trend in the winter flow (total from December to March) (Fig. 5e).

\section{Discussion and result comparison}

The long-term changes in the intercept $a$ (Fig. 3), along with the trends in winter flow and spring temperature, suggest an increasing effective aquifer depth, which may be due to thawing of permafrost within the Abiskojokken catchment. This indication rests on the assumption of no or small changes in other physical catchment characteristics. With respect to the geomorphic characteristics ( $L$ and $A$ ), it is likely they do not change over this period of observation as they evolve at much longer time scales and tend to reach an equilibrium state (Brutsaert, 2008). The assumption of invariance (or more appropriately, minimal change) in hydrologic characteristics is likely valid since the common assumption of exponential decay in hydraulic conductivity with soil depth implies that aquifer depth extension below the previous active soil layer or/and below the permafrost layer would lead to relatively small changes in the depth-average hydraulic conductivity. That is, for a given increase in depth there would be a relatively small change in, for example, depth-averaged hydraulic conductivity. In addition, cryoturbation processes, which allow for mixing of materials from the soil surface to the bedrock in arctic regions and create generally uniform soil properties with depth, may be active in this catchment.

Several simplifying assumptions go into the application of recession flow analysis and hydraulic groundwater theory as it is presented in this study. For example, evapotranspiration and aquifer-slope are not explicitly considered. However, these assumptions have been considered in other studies to not hinder the use of the method in real-world applications (Brutsaert and Nieber, 1977; Troch et. al, 1993; Brutsaert and Lopez, 1998; Malvicini, 2003). With respect 


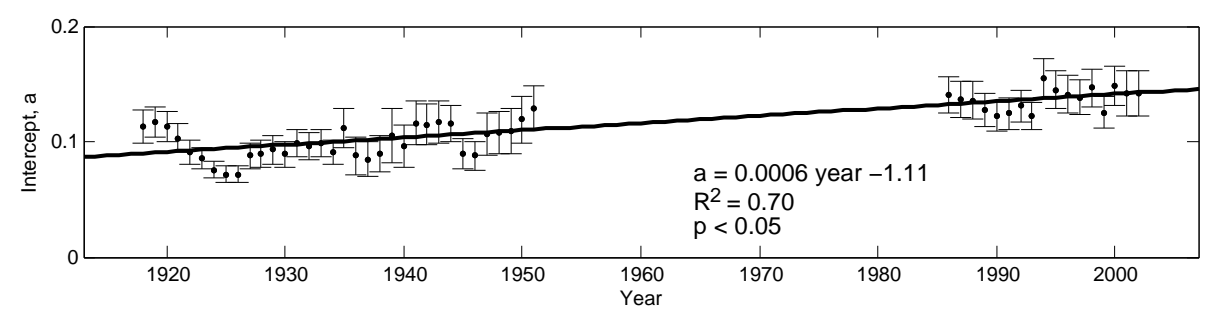

Fig. 3. Time series of the intercept, $a$, from the recession flow analysis with a 5 -year moving window and fixed slope of $b=1$ for the Abiskojokken catchment. Vertical error bars indicate the $95 \%$ confidence interval associated with the estimated intercept for the recession flow analysis.
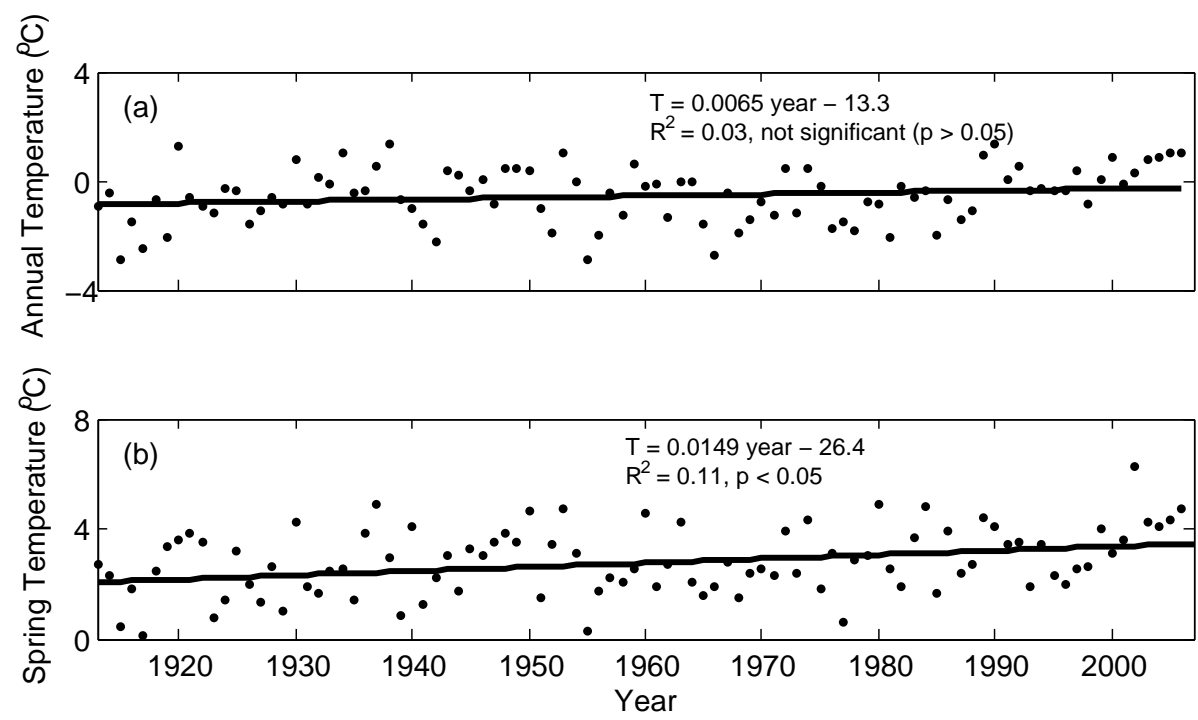

Fig. 4. Time series of (a) average annual temperature and (b) average spring temperature (April-June) for the Abiskojokken catchment.

to evapotranspiration, this lack of hindrance is likely due to a decoupling of upper unsaturated soil layers from a lower saturated zone (Zecharias and Brutsaert, 1988). There are also the simplifications made adopting a Boussinesq aquifer model with spatially constant effective parameters for representing a real-world catchment. Szilagyi and Parlange (1998) found that increasing watershed complexity had minimal effect on the use of recession flow analysis to estimate hydraulic parameters for synthetic catchments. In addition, adopting Eqs. (2) and (3) assumes (via linearization) that the change in saturated thickness over the course of a recession event is small relative to the total saturated thickness. While there are several underlying assumptions, other investigations largely confirm that the simplifications in basin geometry and hydrological processes are not seriously problematic in real-world applications (e.g. Mendoza et al., 2003).

Åkerman and Johansson (2008) reported rates of permafrost thawing, ranging from 0.7 to $1.3 \mathrm{~cm}$ per year, based on 29 years of direct observations in the Abiskojokken region. This direct observation of thawing supports our interpretation of the recession flow analysis. Specifically, it supports the above assumption of minimal influence of change in hydrologic characteristics since there is observed thawing occurring. Based on the analysis in this study (Fig. 3), the change in recession flow intercept would imply an increase in depth-average hydraulic conductivity in addition to the observed permafrost thawing. There is no real physical support for such an interpretation since hydraulic conductivity tends to decay with depth in most arctic systems (Quinton et al., 2000, 2008). Any changes in depth-averaged hydraulic conductivity in Abiskojokken are, thus, likely to be relatively minimal compared to the effect of changes in depth on the storage-discharge relationship.

The recession analysis indication that permafrost is thawing in the Abiskojokken catchment can also be directly tested by estimating an average thawing rate from the present analysis results and comparing it with independently reported permafrost thawing rates for this region. To estimate a thawing rate from our recession flow analysis, we first need to know the permafrost and related effective aquifer depth in the catchment at some reference point in time. Since permafrost is discontinuous with a patchy distribution in the 

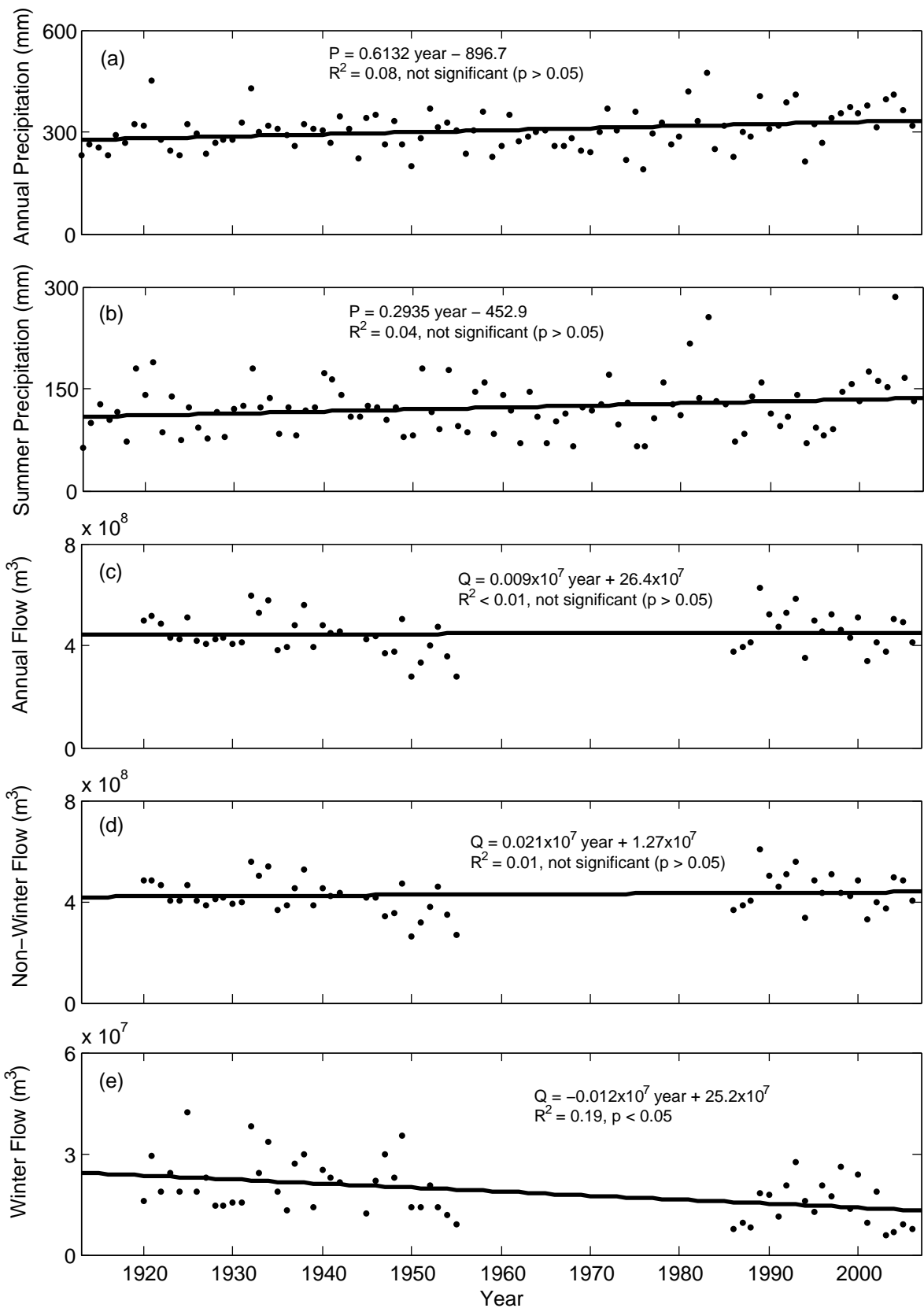

Fig. 5. Time series of (a) total annual precipitation, (b) total summer precipitation (July-September), (c) total annual streamflow, (d) total non-winter streamflow (April-November), and (e) total winter streamflow (December-March) for the Abiskojokken catchment.

landscape, some generalization is required. Åkerman and Malmström (1986) report a depth to permafrost in the catchment of about $1.2 \mathrm{~m}$. We adopt this value as the effective aquifer depth $D_{r}$ in the catchment for reference year 1986 . Substituting into Eq. (3), we derive an expression for the remaining variables, which from above are assumed constant in time, using the specific intercept value $a_{r}$ obtained for the reference year 1986, from the linear intercept trend in Fig. 3. The following expression is then obtained for the change of aquifer depth, $\Delta D$, between the reference year and any other year which should equal the amount of permafrost thawing over the defined period, if that were the reason for the aquifer depth change:

$$
\Delta D=\left(\frac{a}{a_{r}}-1\right) D_{r}
$$

Using Eq. (4), we can estimate the total amount of effective permafrost thawing over a given period of time. This total amount can be used to define an average annual rate following the assumption of a linear trend fitting Fig. 3. This gives 
an estimate for effective permafrost thawing rate of about $0.9 \mathrm{~cm} / \mathrm{yr}$ for the Abiskojokken catchment. This rate agrees well with the range of independently determined thawing rates reported by Åkerman and Johansson (2008) for this region. In addition, using Eq. (4) we would estimate about $0.9 \mathrm{~m}$ of total thaw over the entire 90 -year flow record period.

Since the permafrost is uneven in its distribution, with more permafrost commonly found at higher elevations (Kling, 1996; Beylich et al., 2004; Johansson et al., 2006) and less at lower elevations, our thawing rate estimate must be considered an effective rate that generalizes the whole catchment area and is at best an approximation. The lack of documentation of direct permafrost observations from the early parts of the 20th century makes it difficult to test and confirm the total amount of thawing (about $0.9 \mathrm{~m}$ over the entire 90 -year flow record period) implied by an average effective thawing rate of $0.9 \mathrm{~cm} / \mathrm{yr}$. The 20th century has generally experienced a warmer climate than the Little Ice Age (ca. 1550-1850) with documented decreases in the distribution of permafrost in Sweden (Zuidhoff and Kolstrup, 2000). In general, there has been a decrease in the number and size of palsas, often regarded as one of or the only reliable surface evidence of permafrost in the discontinuous zone (Åkerman and Malmström, 1986), across Scandinavia since the 1960s (Sollid and Sörbel, 1998; Zuidhoff and Kolstrup, 2000). In one of the earliest observations available in the literature, the botanist Harry Smith observed several palsas in mid-latitude Sweden $\left(62^{\circ} 55^{\prime} \mathrm{N}, 12^{\circ} 30^{\prime} \mathrm{E}\right)$ during an expedition in 1910 (Smith, 1911). Nihlén (2000) revisited the location of these palsas and noted a decrease in number and size (reduction in height of about $1 \mathrm{~m}$ ). This documented disappearance or reduction in size of palsas is a strong indicator of significant permafrost change, and most likely thawing, across Scandinavia.

Since flow records tend to be longer and more continuous than records of permafrost observations, flow analysis in general may be attractive for indirect detection of long-term permafrost changes and thawing. Walvoord and Striegl (2007) cite increased winter flow as an indicator of increased groundwater contribution for tributaries of the Yukon River. From this, they infer that permafrost is thawing in the region. We observed the opposite trend in winter discharge in a region of observed permafrost thawing (Fig. 5e). Assuming that winter discharge derives from deeper groundwater reservoirs (beneath the permafrost), this indicates such reservoirs receive less input. Since our catchment is underlain by discontinuous permafrost, there is always recharge to this deeper reservoir. The increasing spring temperature (Fig. 4b) may have led to increasing evapotransporation and a decrease in this recharge leading to an associated decrease in nonwinter flows. However, stream flows are the integral products of many different subsystem fluxes within a catchment, of which all may change in a changing climate. This makes it difficult to relate absolute streamflow changes to a specific individual subsystem flow change. An advantage of using the recession flow analysis outlined in this study is that it indicates a process function change (the recession flow intercept), rather than an absolute flow change, and thereby allows detection of permafrost changes independently of the absolute streamflow changes that integrate and thus may mask different subsystem flow changes within a catchment.

\section{Concluding remarks}

This study of the sub-arctic Abiskojokken catchment in northern Sweden indicates hydrological recession analysis as a useful method for detecting permafrost thawing and its rate. Changes in permafrost should manifest themselves in hydrological function parameters, such as the recession flow intercept, of a catchment. The present approach shows how such parameter change quantifications may be used to infer related changes in effective aquifer and permafrost depth at the support scale of the catchment. Future work is needed to test this approach in other catchments containing permafrost to determine its general applicability across different geomorphologic and climatic settings. In this initial application to the Abiskojokken catchment, however, the specific permafrost thawing and thawing rate results fit well with independent indications and direct rate estimates of permafrost thawing in the region.

Acknowledgements. The authors acknowledge SMHI and ANS for the data used in this study. Funding came from the Swedish Research Council (VR) and the Bert Bolin Centre for Climate Research, which is supported by a Linnaeus grant from VR and The Swedish Research Council Formas.

Edited by: A. Gelfan

\section{References}

Åkerman, H. J. and Johansson, M.: Thawing permafrost and thicker active layers in sub-arctic Sweden, Permafrost Periglac., 19(3), 279-292, 2008.

Åkerman, H. J. and Malmström, B.: Permafrost mounds in the Abisko area, northern Sweden, Geogr. Ann. A, 68(3), 155-165, 1986.

Beylich, A. A., Kolstrup, E., Thyrsted, T., Linde, N., Pedersen, L. B., and Dynesius, L.: Chemical denudation in arctic-alpine Latnjavagge (Swedish Lapland) in relation to regolith as assessed by radio magnetotelluric-geophysical profiles, Geomorphology, 57, 303-319, 2004.

Brown, R. D. and Braaten, R. O.: Spatial and temporal variability of Canadian monthly snow depth, 1946-1995, Atmos. Ocean, 36, 37-54, 1998.

Brutsaert, W.: Hydrology: An Introduction, Cambridge University Press, 605 pp., 2005. 
Brutsaert, W.: Long-term groundwater storage trends estimated from streamflow records: Climatic perspective, Water Resour. Res., 44, W02409, doi:10.1029/2007WR006518, 2008.

Brutsaert, W. and Lopez, J. P.: Basin-scale geohydrologic drought flow features of riparian aquifers in the southern Great Plains, Water Resour. Res., 34, 233-240, 1998.

Brutsaert, W. and Nieber, J. L.: Regionalized drought flow hydrographs from a mature glaciated plateau, Water Resour. Res., 13, 637-643, 1977.

Carey, S. K. and Woo, M. K.: Slope runoff processes and flow generation in a subarctic, subalpine catchment, J. Hydrol., 253, 110129, 2001.

Curtis, J., Wendler, G., Stone, R., and Dutton, E.: Precipitation decrease in the western Arctic, with special emphasis on Barrow and Barter Island, Alaska, Int. J. Climatol., 18, 1687-1707, 1998.

Déry, S. J., Stieglitz, M., McKenna, E. C., and Wood, E. F.: Characteristics and trends of river discharge into Hudson, James, and Ungava Bays, 1964-2000, J. Climate, 18, 2540-2557, 2005.

Déry, S. J. and Wood, E. F.: Teleconnection between the Arctic Oscillation and Hudson Bay river discharge, J. Geophys. Res., 31, L18205, doi:10.1029/2004GL020729, 2004.

Dingman, S. L.: Characteristics of summer runoff from a small watershed in central Alaska, Water Resour. Res., 2, 751-754. 1966.

Dingman, S. L.: Effects of permafrost on stream flow characteristics in the discontinuous permafrost zone of central Alaska, in: North American Contribution to Second International Conference of Permafrost, National Academy of Sciences, Washington, DC, 447-453, 1973.

Dutta, K., Schuur, E. A. G., Neff, J. C., and Zimov S. A.: Potential carbon release from permafrost soils of Northeastern Siberia, Global Change Biol., 12, 2336-2351, 2006.

Hinzman, L.D., Kane, D. L., and Everett, K. R.: Hillslope hydrology in an Arctic setting, in Proceedings, Sixth International Conference on Permafrost, South China Press, Beijing, 257-271, 1993.

Jansson M., Hickler, T., Jonsson, A., and Karlsson, J.: Links between terrestrial primary production and lake mineralization and $\mathrm{CO}_{2}$ emission in a climate gradient in subarctic Sweden, Ecosystems, 11, 367-376, 2008.

Johansson, M., Christensen, T. R., Akerman, H. J., and Callaghan, $\mathrm{T}$. V.: What determines the current presence or absence of permafrost in the Torneträsk region, a sub-arctic landscape in northern Sweden?, Ambio, 35(4), 190-197, 2006.

Kane, D. L., Bredthauer, S. R., and Stein, J.: Subarctic snowmelt runoff generation, in: Proceedings of the Specialty Conference on The Northern Community, edited by: Vinson, T. S., American Society of Civil Engineers, Seattle, Washington, 591-601, 1981.

Kirchner, J. W.: Catchments as simple dynamical systems: Catchment characterization, rainfall-runoff modeling, and doing hydrology backward, Water Resour. Res., 45, W02429, doi:10.1029/2008WR006912, 2009.

King, L.: Zonation and ecology of high mountain permafrost in Scandinavia, Geogr. Ann. A, 68, 131-139, 1986.

Kling, J.: Sorted circles and polygons in northern Sweden, Distribution and Processes, Ph.D. thesis, Department of Physical Geography, Göteborg University, 1996.

Kohler, J., Brandt, O., Johansson, M., and Callaghan, T.: A longterm Arctic snow depth record from Abisko northern Sweden, 1913-2004, Polar Res., 25(2), 91-113, 2006.
Kuchment, L. S., Gelfan, A. N., and Demidov, V. N.: A distributed model of runoff generation in the permafrost regions, J. Hydrol., 240, 1-22, 2000.

McCabe, G. J., Clark, M. P., and Serreze, M. C.: Trends in Northern Hemisphere surface cyclone frequency and intensity, J. Climate, 14, 2763-2768, 2001.

McNamara, J. P., Kane, D. L., and Hinzman, L. D.: An analysis of streamflow hydrology in the Kuparuk River Basin, Arctic Alaska: a nested watershed approach, J. Hydrol., 206, 39-57, 1998.

McNamara J. P., Kane D. L., and Hinzman, L. D.: Hydrograph separations in an Arctic watershed using mixing model and graphical techniques, Water Resour. Res., 33(7), 1707-1719, 1997.

Malvicini, C. F., Steenhuis, T. S., Walter, M. T, Parlange, J.-Y., and Walter, M. F.: Evaluation of spring flow in the uplands of Matalom, Leyte, Philippines, Adv. Water Resour., 28, 1083-1090, 2005.

Mendoza, G. F., Steenhuis, T. S., Walter, M. T., and Parlange, J.Y.: Estimating basin-wide hydraulic parameters of a semi-arid mountainous watershed by recession-flow analysis, J. Hydrol., 279, 57-69, 2003.

Nihlén, T.: Palsas in Harjedalen, Sweden: 1910 and 1998 compared, Geogr. Ann. A, 82(1), 39-44, 2000.

Osterkamp, T. E.: Characteristics of the recent warming of permafrost in Alaska, J. Geophys. Res., 112, F02S02, doi:10.1029/2006JF000578, 2007.

Parlange, J.-Y., Stagnitti, F., Heilig, A., Szilagyi, J., Parlange, M. B., Steenhuis, T. S., Hogarth, W. L., Barry, D. A., and Li, L.: Sudden drawdown and drainage of a horizontal aquifer, Water Resour. Res., 37, 2097-2101, 2001.

Peterson, B. J., Holmes, R. M., McClelland, J. W., Vörösmarty, C. J., Lammers, R. B., Shiklomanov, A. I., Shiklomanov, I. A., and Rahmstor, S.: Increasing river discharge to the Arctic Ocean, Science, 298, 2171-2173, 2002.

Quinton, W. L., Gray, D. M., and Marsh, P.: Subsurface drainage from hummock-covered hillslope in the Arctic tundra, J. Hydrol, 237, 113-125, 2000.

Quinton, W. L., Hayashi M., and Carey S. K.: Peat hydraulic conductivity in cold regions and its relation to pore size geometry, Hydrol. Process., 22(15), 2829-2837, 2008.

Roulet N. T. and Woo, M. K.: Runoff generation in a low arctic drainage basin, J. Hydrol, 101, 213-226, 1988.

Rupp, D. E. and Selker, J. S.: On the use of the Boussinesq equation for interpreting recession hydrographs from sloping aquifers, Water Resour. Res., 42, W12421, doi:10.1029/2006WR005080, 2006 a.

Rupp, D. E. and Selker, J. S.: Information, artifacts, and noise in dQ/dt-Q recession analysis, Adv. Water Resour., 29, 154-160, $2006 \mathrm{~b}$.

Santeford, H. S.: Toward hydrologic modeling of the black spruce/permafrost ecosystem of interior Alaska, in: Proceedings 30th Alaska Science Conference, Fairbanks, Alaska, 1979.

Serreze, M. C., Walsh, J. E., Chapin III, F. S., Osterkamp, T., Dyurgerov, M., Romanovsky, V., Oechel, W. C., Morison, J., Zhang, T., and Barry, R. G.: Observational evidence of recent change in the northern high-latitude environment, Climatic Change, 46, 159207, 2000.

Slaughter, C. W. and Kane, D. L.: Hydrologic role of shallow organic soils in cold climates, in: Proceedings, Canadian Hydrol- 
ogy Symposium 79 - Cold Climate Hydrology, National Research Council of Canada, Ottawa, 380-389, 1979.

Stieglitz, M., Déry, S. J., Romanovsky, V. E., and Osterkamp, T. E.: The role of snow cover in the warming of Arctic permafrost, Geophys. Res. Lett., 30(13), 1721, doi:10.1029/2003GL017337, 2003.

Smedberg, E., Mörth, C.-M., Swaney, D. P., and Humborg, C.: Modelling hydrology and silicon-carbon interactions in taiga and tundra biomes from a landscape perspective: Implications for global warming feedbacks, Global Biogeochem. Cy., 20, GB2014, doi:10.1029/2005GB002567, 2006.

Smith, H.: Postglaciala regionförskjutningar I norra Härjedalens och södra Jämtlands fjälltrakter, Geol. För. Förh., 33, 503-530, 1911.

Sollid, J. L. and Sorbel, L.: Palsa bogs as a climate indicator examples from Dovrefjell, southern Norway, Ambio, 27(4), 287291, 1998.

Szilagyi, J. and Parlange, M. B.: Baseflow separation based on analytical solutions of the Boussinesq equation, J. Hydrol., 204, 251-260, 1998.

Troch, P. A., De Troch, F. P., and Brutsaert, W.: Effective water table depth to describe initial conditions prior to storm rainfall in humid regions, Water Resour. Res., 29, 427-434, 1993.
Walsh, J. E.: Global atmospheric circulation patterns and relationships to Arctic freshwater fluxes, in The Freshwater Budget of the Arctic Ocean, edited by: Lewis, E. L., Jones, E. P., Lemke, P., et al., NATO Science Series 2: Environmental Security, Vol. 7, Kluwer Academic, 21-43, 2000.

Walvoord, M. A. and Striegl, R. G.: Increased groundwater to stream discharge from permafrost thawing in the Yukon River basin: Potential impacts on later export of carbon and nitrogen, Geophys. Res. Lett., 34, L12402, doi:10.1029/2007GL030216, 2007.

Woo, M. K., Kane, D. L., Carey, S. K., and Yang, D.: Progress in permafrost hydrology in the new millennium, Permafrost Periglac., 19, 237-254, 2008.

Yamazaki, Y., Kubota, J., Ohata, T., Vuglinsky, V., and Mizuyama, T.: Seasonal changes in runoff characteristics on a permafrost watershed in the southern mountainous region of eastern Siberia, Hydrol. Process., 20, 453-467, 2006.

Zuidhoff, F. S. and Kolstrup, E.: Changes in palsa distribution in relation to climate change in Laivadalen, northern Sweden, especially 1960-1997, Permafrost Periglac., 11, 55-69, 2000.

Zecharias, Y. B. and Brutsaert, W.: Recession characteristics of groundwater outflow and baseflow from mountainous watersheds, Water Resour. Res., 24(10), 1651-1658, 1998. 